\title{
Pelagia Noctiluca Jellyfish: Can Lesions and Symptoms be Prevented or Ameliorated?
}

\author{
Laurence Mathieu ${ }^{1}$, Joel Blomet ${ }^{1}$, Alan H. Hall ${ }^{2,3^{*}}$ \\ ${ }^{1}$ Laboratoire Prevor, Moulin de Verville, 95760 Valmondois, France \\ ${ }^{2}$ Toxicology Consulting and Medical Translating Services, Azle and Springtown, Texas, USA \\ ${ }^{3}$ Colorado School of Public Health, University of Colorado-Denver, Denver, Colorado USA
}

*Corresponding author: Alan H. Hall, Toxicology Consulting and Medical Translating Services, P.O. Box 1255, Azle, Texas 76098-1255, USA, Tel: 1-817-919-3208; E-mail: OldEDDoc@gmail.com

\begin{abstract}
Objective: Pelagia noctiluca is a very common jellyfish found on European and Mediterranean coasts. Its venom can induce small to severe skin lesions and systemic toxicity. Hypertonicity and modulation of $\mathrm{pH}$ could prevent more nematocysts from discharging and relieve symptoms.

Methods: This open-label observational study was performed on Mediterranean beaches by rescuers under the authorization of the Ministère de l'Interieur en France (French Ministry of the Interior). Lesions were evaluated for size, general appearance, erythema, pain, and edema. A hypertonic amphoteric solution, Jellywash ${ }^{\circledR}$ solution (Laboratoire Prevor, Valmondois, France), was used for decontamination regardless the delay.

Results: 64 victims were exposed to Pelagia noctiluca jellyfish. 78\% were $>30$ years old, with 27 females and 37 males. $83 \%$ of the lesions were small (less than $50 \mathrm{~cm}^{2}$ ). $78 \%$ of the exposed victims were treated within the first 40 minutes. Decontamination had positive results for general appearance in $80 \%$ of the victims. Pain decreased in $97 \%$ of cases with complete relief in $58 \%$ and no effect in 3\%. Decontamination was followed by decreased edema in $86 \%$ of cases, had a minor effect in $8 \%$, and no effect in $6 \%$.

Conclusion: Decontamination with a hypertonic amphoteric solution can potentially help ameliorate or prevent development of lesions and symptoms due to contact with Pelagia noctiluca jellyfish.
\end{abstract}

Keywords: Pelagia noctiluca; Jellyfish; Venom; Hypertonicity, Amphoteric agent

\section{Introduction}

Pelagia noctiluca is a very common jellyfish on European and Mediterranean coasts ${ }^{[1]}$ and is also found in other ocean waters ${ }^{[2]}$. Regularly, there are invasions of groups of Pelagia noctiluca jellyfish on the French Mediterranean coasts ${ }^{[3]}$ which perturbate bathers' recreational activities by stings. These Pelagia noctiluca invasions have been recurrent over the past 20 years and currently cannot be predicted, although the factors that encourage them are known: trophic, as well as hydrological variations, and ocean current and weather factors.

Pelagia noctiluca is a jellyfish in the form of a blue and pink mushroom with a parasol approximately 12 centimeters in diameter (15 $\mathrm{cm}$ maximum) with 4 buccal arms festooned with 8 transparent fishing filaments which are very urticant and which exceed that of other sites on the organism, such as the pink and mauve varicosities on the parasol and buccal arms ${ }^{[4]}$.

It belongs to the Scyphozoa (true Jellyfish) class of the phylum Cnidaria. Pelagia noctiluca venom can induce small to severe skin lesions ${ }^{[1]}$ and systemic toxicity $^{[5]}$. Local symptoms are erythema, edema, dermonecrosis or vesicles, whereas systemic toxic effects can be cardiac or on the musculature or nervous system. The
Received date: Sep 21, 2018

Accepted Date: Dec 27, 2018

Published Date: Dec 29, 2018

Citation: Hall, A.H. I Pelagia Noctiluca Jellyfish: Can Lesions and Symptoms be Prevented or Ameliorated? (2018) J Marine Biol Aquacult 4(1): 48- 52.

Copy Rights: (C) 2018 Hall, A.H. This is an Open access article distributed under the terms of Creative Commons Attribution 4.0 International License. 
effects depend on the quality and the age of the jellyfish and on individual human susceptibility.

Chemosensitive discharge has been seen following treatment of excised Pelagia noctiluca oral arm nematocysts with sugars, amino compounds (i.e., glutathione), mucins, and nucleotides ${ }^{[6]}$. Nematocyte discharge involves both chemical and mechanical modes of excitation ${ }^{[7]}$.

The venoms of jellyfish are complex mixtures containing such substances as bioactive lipids, neurotoxic peptides, proteinaceous porins, and various other small molecules ${ }^{[2]}$. Tubules, portions of which may be left in the skin following envenomation, contain chitins and collagens ${ }^{[2]}$. This jellyfish is one of the most venomous in the Mediterranean. Its stings can be very painful because of the venom emitted from its urticant cells. Stings from Pelagia noctiluca are generally not fatal, but can result in significant cutaneous lesions and in anaphylactic $\operatorname{shock}^{[8]}$.

Several potential treatments have previously been evaluated ${ }^{[5,9]}$. Washing with sea water suggests that hypertonicity could participate in prevention of nematocyst discharge as well as relieve pain ${ }^{[9]}$. Tentacle removal as well as topical $\mathrm{BaCl}_{2}$, $\mathrm{MgCl}_{2}$, baking soda slurry $\left(\mathrm{NaHCO}_{3}\right)$, and methylated spirits can block venom discharge ${ }^{[10]}$. Topical vinegar, $\mathrm{NaCl}$, Choline- $\mathrm{Cl}$ and ethanol seem to increase venom discharge ${ }^{[10]}$.

Nevertheless, the mechanisms of Pelagia noctiluca nematocyst release have been identified. Extreme $\mathrm{pH}$ values $(<2$ and $>11)$ have been identified as inducing nematocyst discharge ${ }^{[11]}$, while mild acidic $\mathrm{pH}$ values $(4.5,6.5)$ prevent $\mathrm{it}^{[5,10,12]}$, suggesting that modulation of $\mathrm{pH}$ could prevent more nematocysts from discharging and relieve symptoms ${ }^{[10,13]}$. Treatment with $\mathrm{La}^{2+}, \mathrm{Gd}^{3+}$ and $\mathrm{Ca}^{2+}$ also inhibit nematocyst release, as well as distilled water, lidocaine, alcohols, acetic acid, ammonia and heavy metals such as zinc, cadmium, cobalt and lanthanum ${ }^{[7,13]}$. These results suggest that environmental changes can affect homeostasis and function of Cnidaria.

Based on this information, a hypertonic amphoteric solution, Jellywash ${ }^{\circledR}$ solution (Laboratoire Prevor, Valmondois, France), was developed and clinically evaluated to understand if these main properties could help to prevent or ameliorate dermal lesions and symptoms following exposure to nematocysts from true jellyfish, and especially Pelagia noctiluca.

\section{Methods}

This open-label observational study was performed on French Mediterranean beaches with rescuers under the authorization of the Ministère de l'Interieur en France (French Ministry of the Interior). An observational series of case reports was collected by first aid rescuers with the following information:

- Demographic data: age, gender

- Initial lesion: lesion size estimation was based on daily life objects (coin, credit card and postcard) to simplify the measurements. When the size of the lesion was qualified as "other", it means that the contact area was small, so there was no visual lesion but symptoms such as pain were present.

- Delay before washing was noted.

- Decontamination: Rinsing was performed by rescuers with an open-label hypertonic amphoteric solution, Jellywash ${ }^{\circledR}$ solution, until pain disappeared.
- Benefit of decontamination was observed based on general appearance improvement and redness, pain or edema decrease.

\section{Results}

Sixty-four victims exposed to Pelagia noctiluca jellyfish on French Mediterranean beaches were studied during August, 1999. Seventy-eight percent were $>30$ years old (Figure 1) (27 females; 37 males).

\section{Percentage of victims per age}

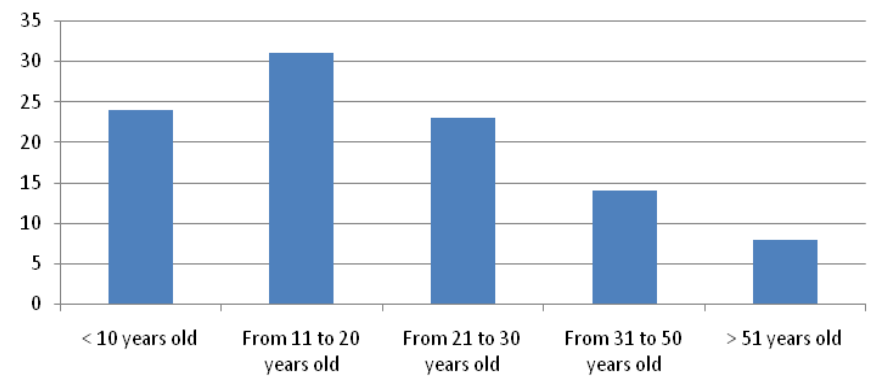

Figure 1: Distribution of victims' ages

Simple objects from daily life were used to calibrate and simplify measurements with approximately and respectively the following surface areas: $6.6 \mathrm{~cm}^{2}$ (coin), $46.2 \mathrm{~cm}^{2}$ (credit card), and $155 \mathrm{~cm}^{2}$ (postcard). Eighty-three percent of the exposure lesions were small $\left(>50 \mathrm{~cm}^{2}\right)$ (Figure 2$)$.

\section{Affected surface per victims}

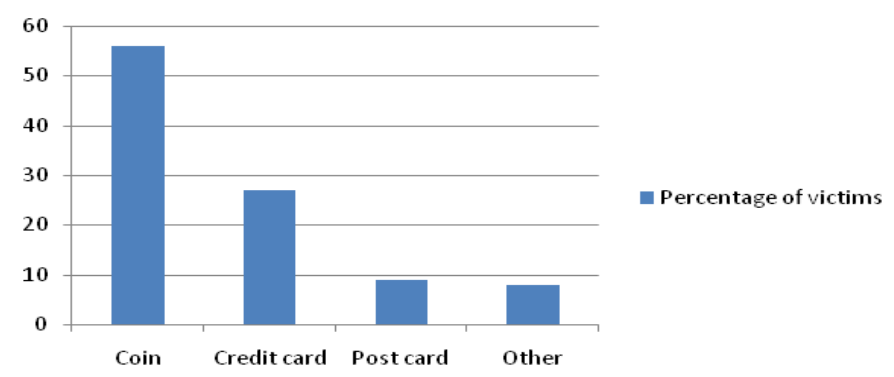

Figure 2: Distribution of lesion sizes

Of the exposed victims, $78 \%$ were treated with $100 \mathrm{~mL}$ of Jellywash ${ }^{\circledR}$ solution (Figure 3 ) sprayed over the lesions during 50 seconds within 40 minutes following exposure (Figure 4). For a skin lesion equivalent to or less than a hand surface area, $100 \mathrm{~mL}$ of Jellywash ${ }^{\circledR}$ solution was found to be sufficient for decontamination.

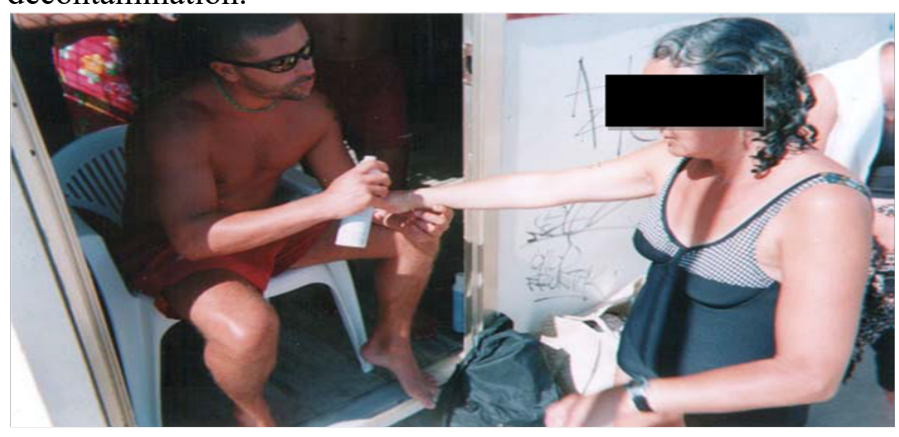

Figure 3: Decontamination of a lesion due to Pelagia noctiluca with Jellywash ${ }^{\circledR}$ solution 


\section{Delay of intervention for victims}

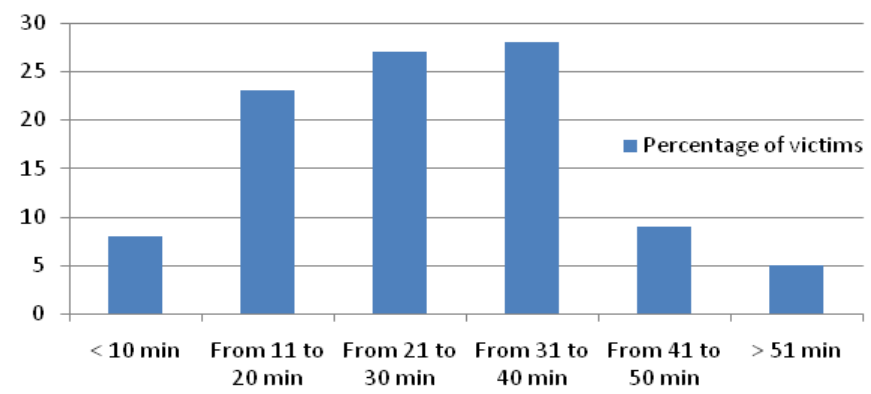

Figure 4: Delay of intervention for victims

A victim with a Pelagia noctiluca lesion being decontaminated with Jellywash ${ }^{\circledR}$ solution is shown in Figure 3. The range of delay to intervention with Jellywash ${ }^{\circledR}$ solution for victims is shown in Figure 4.

Decontamination with Jellywash ${ }^{\circledR}$ solution seemed to be beneficial for general appearance in $80 \%$ of the victims, while a minor effect or no effect was observed for, respectively, $17 \%$ and $3 \%$ of the victims (Figure 5 ).

\section{Effect on decontamination on general aspect}

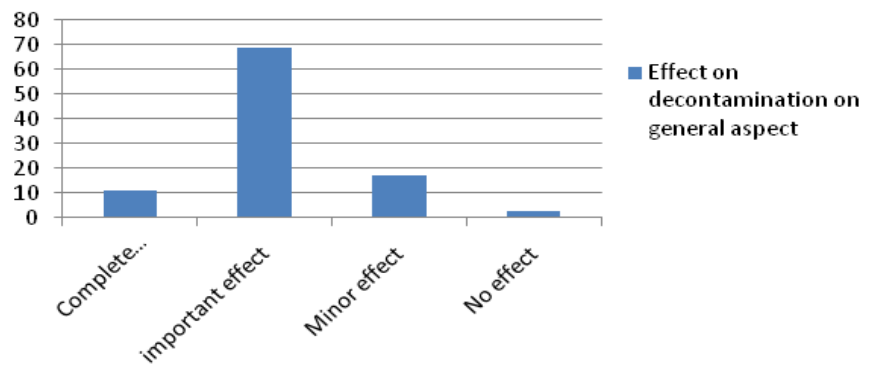

Figure 5: General appearance improvement following decontamination with Jellywash ${ }^{\circledR}$ solution

Figures $6 a, 6 b$, and $6 c$ show the general appearance evolution of a lesion in a child with exposure to Pelagia noctiluca before and after decontamination with Jellywash ${ }^{\circledR}$ solution: before decontamination, Figure $6 \mathrm{a} ; 15$ minutes after decontamination, Figure $6 b ; 30$ minutes after decontamination, Figure $6 c$.

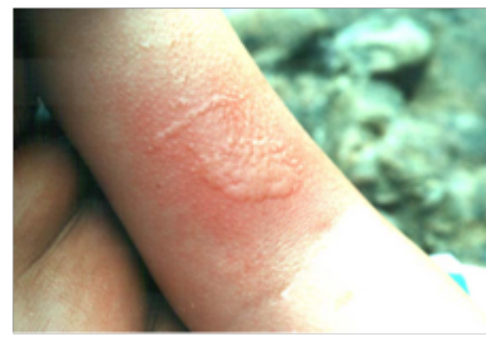

Figure 6a: before decontamination

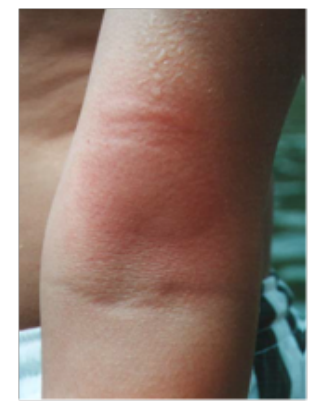

Figure 6b: 15 minutes after decontamination

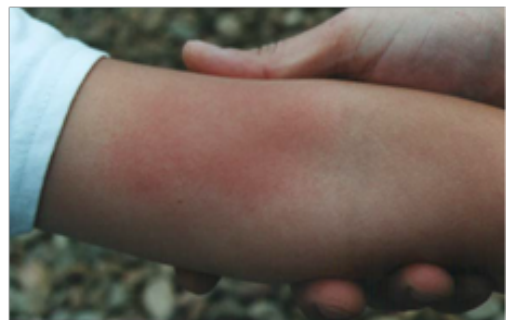

Figure 6c: 30minutes after decontamination

Figures 6a, 6b, and 6c: General appearance evolution of a lesion decontaminated with Jellywash ${ }^{\circledR}$ solution in a child

Figures $7 \mathrm{a}, 7 \mathrm{~b}$, and $7 \mathrm{c}$ show the evolution of Pelagia noctiluca lesions on the neck and face of a young girl before and after Jellywash ${ }^{\circledR}$ solution decontamination: before decontamination, Figures $7 \mathrm{a}$ and $7 \mathrm{~b}$; after decontamination, Figure $7 \mathrm{c}$.
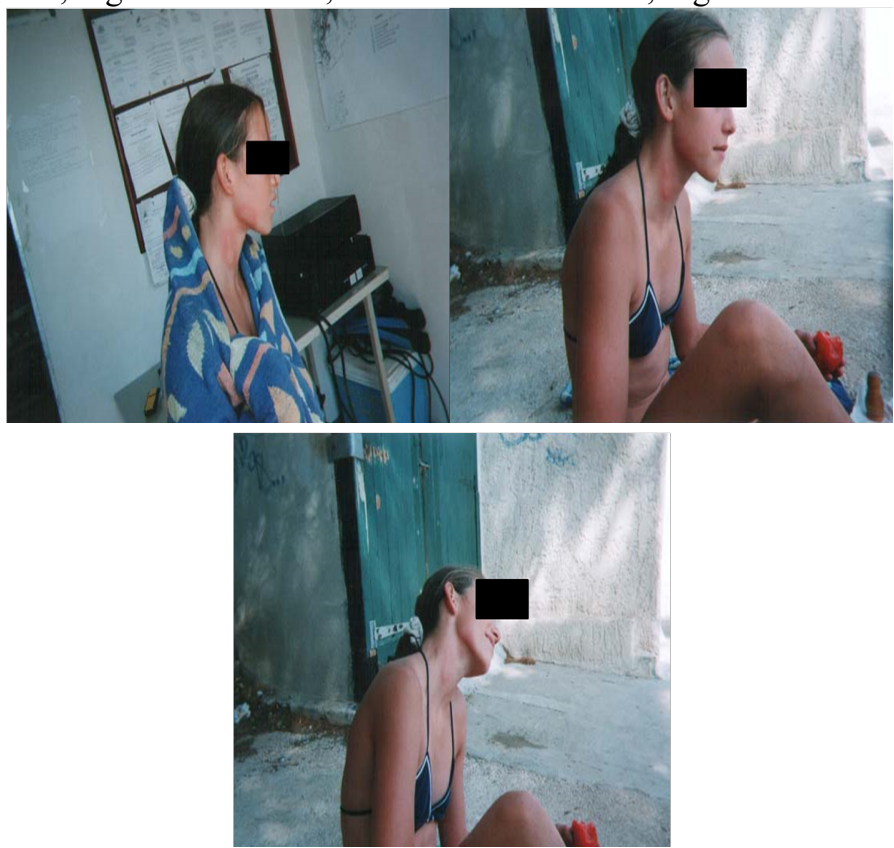

Figures 7a, 7b, and 7c: Evolution of the lesion of the neck and face in a young girl: a and b) initial lesion; c) after Jellywash ${ }^{\circledR}$ decontamination.

Complete disappearance or significant decreases of redness (erythema) (Figure 8) was observed respectively in $11 \%$ and $44 \%$ of victims, while minor effects were observed in $42 \%$ and there was no effect in $3 \%$.

\section{Effect on redness of lesions}

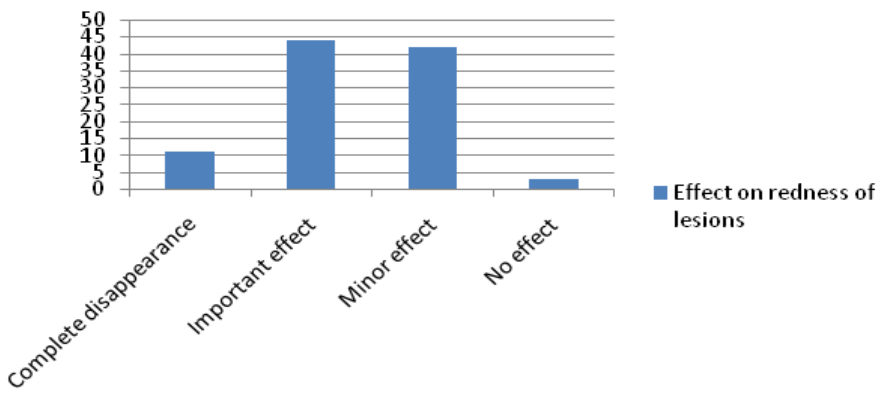

Figure 8: Effect of decontamination with Jellywash ${ }^{\circledR}$ solution on redness (erythema) induced by Pelagia noctiluca lesions 
Pain decreased in $97 \%$ of victims with complete relief in $58 \%$; there was no effect in $3 \%$ (Figure 9). Severe pain was observed in some cases so that the victims, even adults, were crying and screaming.

\section{Effect on pain}

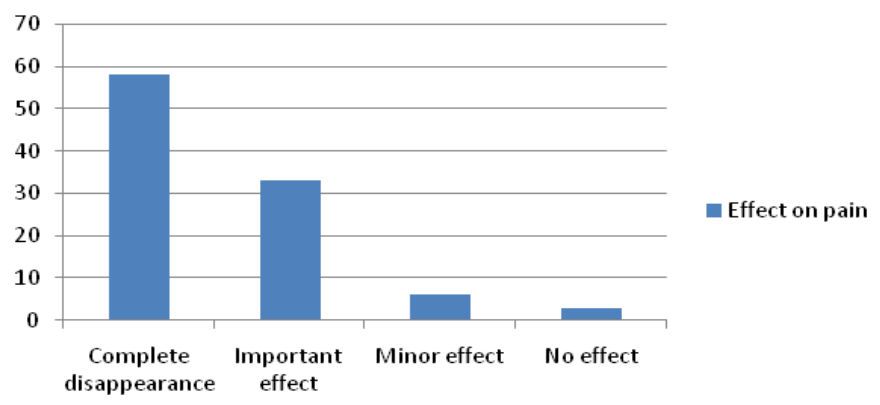

Figure 9: Effect of decontamination with Jellywash ${ }^{\circledR}$ solution on pain induced by Pelagia noctiluca lesions

Decontamination of lesions due to Pelagia noctiluca with Jellywash ${ }^{\circledR}$ solution was associated with a decrease in edema in $86 \%$ of victims (Figure 10 ). There was a minor effect in $8 \%$ and no effect in $6 \%$.

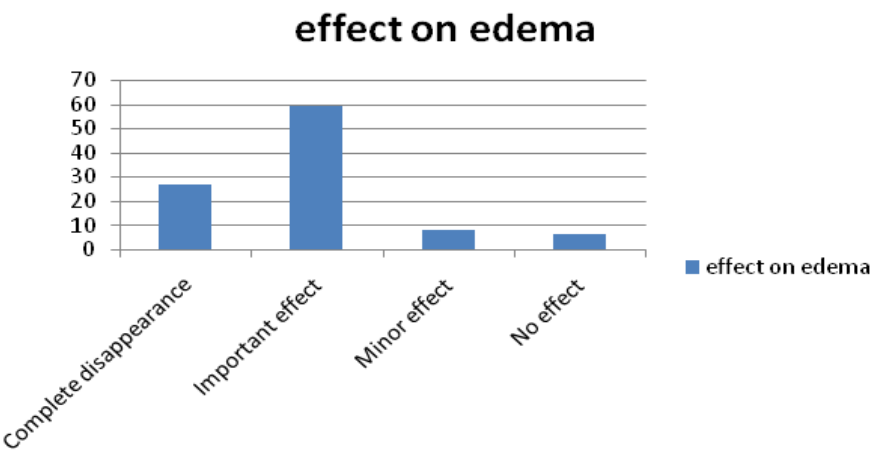

Figure 10: Effect of decontamination with Jellywash ${ }^{\circledR}$ solution on edema induced by Pelagia noctiluca lesions

The delay to intervention with Jellywash ${ }^{\circledR}$ solution was short and pain relief was observed after spraying a small amount of this solution. When the victim had felt pain for some time, longer spraying was required to decrease pain until no beneficial effect was observed with a delay $>50$ minutes.

No adverse effects were observed amongst victims decontaminated with Jellywash ${ }^{\circledR}$ solution, confirming its innocuous nature (non-irritant, non-toxic, non-sensitizing) and its capability to limit the effects of Pelagia noctiluca envenomation.

\section{Discussion}

In France, jellyfish are present on all Mediterranean coasts ${ }^{[1]}$. Similar species can be found on Maryland and Florida coasts and elsewhere. Millions of jellyfish stings occur each year, usually on the lower and upper extremities ${ }^{[14,15]}$. Urticant cells (nematocysts) discharge venom into the victim's skin with a sting after a physical stimulus (contact) or a chemical stimulus (difference of osmotic pressure) even if the animal is stranded or dead.

Since the 1980's, a proliferation of jellyfish in the Mediterranean Sea has been observed due to environmental modification. The present study was performed on French Mediterra- nean Sea beaches where jellyfish are often more urticant. Among these jellyfish, Pelagia noctiluca is the more urticant and can induce local and systemic effects. Among local effects, pain ${ }^{[1]}$ can be severe. Pain can be compared to an electrical shock or a burn so the symptom is often called a "jellyfish burn". Preventing nematocyst discharge or at least limiting venom diffusion could protect against local and systemic effects.

Various treatments have previously been evaluated and seem to provide for each one aspect of the overall solution ${ }^{[5]}$. Some are able to stop pain, others block venom discharge, and still others limit systemic effects ${ }^{[5]}$. Physical and chemical environmental alterations can increase or prevent nematocyst discharge. The environmental $\mathrm{pH}$ value seems to play a role ${ }^{[1]}$, as well as osmotic pressure and chelation ${ }^{[9,10,13]}$. A systematic literature review regarding the debate over whether hot water immersion or ice packs are appropriate first aid measures to decrease the pain of jellyfish envenomations found that most published studies concluded that hot water immersion was the better modality for reducing pain and improving outcome ${ }^{[16]}$.

In the present cases series, Jellywash ${ }^{\circledR}$ solution was shown to be efficacious for limiting local symptoms such as redness, edema and pain. Jellywash ${ }^{\circledR}$ solution is a hypertonic solution ( $\sim 800$ mosmoles $/ \mathrm{kg})$. It is also an amphoteric solution, which means that the solution can control the $\mathrm{pH}$ environment in a subtle way, without generating heat release as is observed with classical chemical neutralization. Jellywash ${ }^{\circledR}$ solution does not contain any analgesic or anti-allergenic substances. Its efficacy may involve both physical and chemical properties required to avoid or limit nematocyst discharge and thus development of or amelioration of symptoms. This is the first case series that shows the interest of a hypertonic amphoteric solution such as Jellywash ${ }^{\circledR}$ solution to limit Pelagia noctiluca venom effects.

This study also shows that delay to Jellywash ${ }^{\circledR}$ solution intervention is a key parameter for a good outcome for the victim. It is best to not let the pain be initiated. Pain can mean that diffusion of the venom has already begun and systemic effects might occur as a consequence.

\section{Conclusion}

Based on the present clinical open-label observational case series, decontamination with a hypertonic amphoteric solution can potentially prevent or ameliorate development of lesions and symptoms due to contact with Pelagia noctiluca jellyfish. Further investigations based on both experimental data and comparative clinical studies will help to confirm the mechanisms of Pelagia noctiluca venom and the potential benefit of decontamination with a hypertonic and amphoteric solution.

Conflict of Interest Statement: Dr. Mathieu and M. Blomet are employees of Laboratoire Prevor, Valmondois, France, and manufacturer of Jellywash ${ }^{\circledR}$ solution. Dr. Hall is a paid consultant to Laboratoire Prevor.

Funding Source: Laboratoire Prevor, Valmondois, France provided the Jellywash ${ }^{\circledR}$ solution used in this study at no cost.

This study was performed under the authorization of the Ministère de l'Interieur en France (French Ministry of the Interior). 
Informed Consent/Human Subjects Protection: Because this was a study of first aid treatment by rescuers on French Mediterranean beaches, written consent was impractical. Oral consent from the victims was obtained in every case.

Acknowledgements: The authors thank all the first aid rescuers who actually treated the victims and collected the data.

\section{References}

1. Marino, A., Crupi, R., Muscli, G., et al. Morphological integrity and toxicological properties of Pelagia noctiluca (Scyphozoa) nematocysts. (2006) Chemistry and Ecology 22(1): S127-S131.

Pubmed | Crossref | Others

2. Tibballs, J., Yanagihara, A.A., Turner, H.C., et al. Immunological and toxinological responses to jellyfish stings. Inflamm. (2011) Allergy Drug Targets 10(5): 438-436. Pubmed | Crossref | Others

3. Hecq, J.H., Goffart, A., Collignon, A., et al. The variability of the jellyfish Pelagia noctiluca (Forskäl, 1775) in the Calvi bay (Corsica) in relation to the environment.

Pubmed $\mid$ Crossref $\mid$ Others

4. Paul Ricard Oceanographic Institute.

Pubmed $\mid$ Crossref $\mid$ Others

5. Morabito, R., Marino, A., Dossena, S., et al. Nematocyst discharge in Pelagia nociluca (Cnidaria, Scyphozoa) oral arms can be affected by lidocaine, ethanol, ammonia, and acetic acid. (2014) Toxicon 83: 52-58.

Pubmed | Crossref | Others

6. Morabito, R., Marino, A., La Spada, G. Nematocytes' activation in Pelagia noctiluca (Cnidaria, Scyphozoa) oral arms. (2012) J Comp Physiol A 198(6): 419-426. Pubmed | Crossref | Others

7. Salleo, A., La Spada, G., Barbera, R. Gadolinium is a powerful blocker of the activation of nematocytes of Pelagia noctiluca. (1994) J Exp Biol 187: 201-206.

Pubmed | Crossref $\mid$ Others

8. Cegolon, L., Heymann, W.C., Lange, J.H., et al. Jellyfish stings and their management: A review. (2013) Mar. Drugs 11(2): 523-550.

Pubmed | Crossref | Others
9. Morabito, R., Marino, A., Lauf, P.K., et al. Sea water acidification affects osmotic swelling, regulatory volume decrease and discharge in nematocytes of the jellyfish Pelagia noctiluca. (2013) Cell Physiol Biochem 32(7): 77-85.

Pubmed | Crossref | Others

10. Salleo, A., La Spada, G., Falzea, G., et al. Discharging effects of anions and inhibitory effect of divalent cations on isolated nematocysts of Pelagia noctiluca. (1984) Mol Physiol 5: 25-34.

Pubmed $\mid$ Crossref $\mid$ Others

11. Salleo, A., La Spada, G., Falzea, G., et al. pH-induced collapse of the capsular wall in isolated nematocysts of Pelagia noctiluca. (1984) Cell Mol Biol 30(1): 91-94.

Pubmed | Crossref $\mid$ Others

12. Morabito, R., Marino, A., La Spada, G., et al. The venom and the toxicity of Pelagia noctiluca (Cnidaria: Scyphozoa). A review of three decades of research in Italian laboratories and future perspectives. (2015) J Biol Res 88(2): 173-178. Pubmed | Crossref | Others

13. Morabito, R., Dossena, S., La Spada, G., et al. Heavy metals affect nematocysts discharge response and biological activity of crude venom in the jellyfish Pelagia noctiluca (Cnidaria, Scyphozoa). (2014) Cell Physiol. Biochem 34(2): 244-254.

Pubmed | Crossref | Others

14. Queruel, P., Bernard, P., Goy, J., et al. Envenomations due to Pelagia noctiluca jellyfish on our mediterranean coasts [Envenimations par la méduse Pelagia noctiluca sur nos côtes méditerranéennes] [French]. (2000) Med Press 29: 188. Pubmed | Crossref $\mid$ Others

15. Queruel, P., Bernard, P., Goy, J., et al. Severe envenomations by Pelagia Noctiluca [Envenimations sévères par la méduse Pelagia Noctiluca] [French]. (2000) JEUR 1-2: A67.

Pubmed $\mid$ Crossref $\mid$ Others

16. Wilcox, C.L., Yanagihara, A.A. Heated debate: Hot-water immersion or ice packs as first aid for Cnidarian envenomations? (2016) Toxins (Basel) 8(4): 97.

Pubmed | Crossref | Others

Submit your manuscript to Ommega Publishers and we will help you at every step:

- We accept pre-submission inquiries

- Our selector tool helps you to find the most relevant journal

- We provide round the clock customer support

- Convenient online submission

- Thorough peer review

- Inclusion in all major indexing services

- Maximum visibility for your research

Submit your manuscript at OMMEgA Publishers

https://www.ommegaonline.org/submit-manuscript 